\title{
THE INFLUENCE OF GENDER DIVERSITY, NATIONALITY, AND EDUCATION OF THE BOARD OF DIRECTORS ON CSR IN INDONESIA SHARIA BANKING
}

\author{
Dessy Noor Farida \\ Fakultas Ekonomi dan Bisnis Islam UIN Walisongo Semarang \\ Jl.Prof.Dr.Hamka No 3-5 \\ dessy_nf@walisongo.ac.id
}

\begin{abstract}
Public awareness of the damage to the surrounding environment due to the industrial activities of large companies, making the public need information about the extent to which the company is responsible for the damage. To maintain the stability of its business, the company is expected to be able to contribute to the community and its environment by implementing CSR. Diversity of directors within an organization can create new norms and hopes that can be a strong driver for implementing CSR in developing countries. This study aims to examine the effect of diversity on the board of directors on CSR disclosure in Indonesian Sharia banking. This research is quantitative. The sample used was all Islamic Commercial Banks in Indonesia totaling 13 banks. Technical analysis of data using multiple linear regression tests. The results confirm that national diversity affects the disclosure of CSR, but gender diversity and educational diversity are not significant to CSR disclosure. This study has an adjusted R2 of $65.6 \%$.
\end{abstract}

Keywords: Gender diversity, nationality diversity, CSR disclosure

\section{Introduction}

Public awareness of the damage to the surrounding environment due to the industrial activities of large companies, making the public need information about the extent to which the company is responsible for the damage. The industrialization that is carried out continuously causes a negative impact on the surrounding environment. This is because many industries do not pay attention to the balance of the ecosystem so that environmental pollution cannot be avoided.

With the environmental pollution that occurs due to industry activities, causing loss of public trust and stakeholders associated with how the company is responsible for the damage that has occurred. Stakeholders and investors need more information regarding how the company treats its environment. In response, management discloses social and environmental information through annual 
reports to meet the expectations of stakeholders.

The main purpose of disclosure is to increase transparency, accountability, and reduce agency costs and reduce information costs on the stock market. Previous research also found evidence that disclosures made by companies related to their CSR activities (Corporate Social Responsibility) have reflected the company's performance, trust, and reputation of the company concerned (Aguilera, Williams, Conley, \& Rupp, 2006). To maintain the stability of its business, the company is expected to be able to contribute to society and the environment by implementing Corporate Social Responsibility (CSR).

CSR is one form of implementation of Islamic business ethics. Business actors or companies are required to have the characteristics of shidiq, trust, fathanah, tabligh and istiqomah. With these characteristics, the company will have the responsibility to fulfill its obligations, always improve the quality of its products, be more open, honest and do the best in everything (Grace, 2017)

Diversity or diversity within an organization can create new norms and hopes that can be a powerful driver for implementing corporate social responsibility in developing countries. New norms can create pressure for companies to adopt practices that can ensure corporate accountability. Diversity can also create a competitive advantage for companies by increasing creativity, more flexible systems, and skills in solving problems better. A variety of perspectives can result in better decisions and deeper analysis to achieve and improve corporate social responsibility goals (El-bassiouny \& El-Bassiouny, 2018).

In a study conducted by the Research Center for Governance, the National University of Singapore (NUS) Institution and Organizations which examined 100 companies in four countries namely Indonesia, Malaysia, Singapore, and Thailand stated that companies in Indonesia have a lower quality of social responsibility when compared to companies in other countries. This is due to the company's lack of understanding of CSR practices, which causes the low quality of CSR operations (Teraspr, 2016).

The low quality of CSR operations in Indonesia is one of the responsibilities of the board of directors. The board of directors is a party that has an important role in making policy in the company. Diversity in the board of directors will affect the quality of CSR disclosure of a company. This study aims to further understand the diversity of the board of directors (gender, nationality, and education) in CSR disclosure, especially in the sharia banking sector in Indonesia. 
Research on the influence of the diversity of the board of directors associated with CSR disclosure has not been done much in Indonesia, especially in the Sharia banking sector. The majority of previous research has focused more on aspects of gender diversity. Whereas in this study, diversity of directors is not only measured by gender diversity, but also in terms of nationality and education of the directors. The results of research on the influence of diversity of directors on CSR disclosure is still very diverse. This is what motivates the study.

\section{Research methods}

This research is a quantitative study using multiple linear regression analysis models using SPSS 23 software. The population of this study is all Sharia Commercial Banks in Indonesia. The number of BUS in Indonesia is 13 banks with a 4-year observation period, from 2015 to 2018 . So the total observation data is 52 data.

The dependent variable of this study is CSR disclosure measured using the ISR (Islamic Social Reporting Index) which is a measure of the implementation of social performance. The ISR index consists of 38 items in 6 categories (R. Haniffa, 2002).

The independent variable of this research is the diversity of the board of directors. The diversity of the board of directors is measured using gender diversity, educational diversity and nationality diversity. Control variables are also used in this study, including the size of the board, company size and independent commissioners.

\section{Hypothesis Formulation}

The existence of women on the board of directors apparently has an influence on CSR disclosure. According to Seirstad the role of female directors is twofold, the first because of business and the second because of justice. The first opinion is based on the premise that having a female director on the board of directors will add new capabilities and can improve business performance. Whereas the second opinion is based on the premise that companies need to build heterogeneity on the board of directors to present gender equality in one team (Martínez, Oms, \& Olcina-Sempere, 2018).

According to Stephenson's research, the reason why women should occupy a position on the board of directors, the first is because research shows that the board of directors whose members are more women compared to male directors is more concerned with auditing and oversight and risk control. The second reason is that women will help companies attract and retain potential female employees and promote positive attitudes in the community of female employees in the company. The 
third reason is that women directors not only focus on financial performance measures, but also emphasize non-financial performance measures such as innovation and social responsibility (Stephenson, 2004).

Diversity will increase creativity and innovation, which in turn will lead to effective decision making (Carter, David A; Simkins, Betty; Simpon, 2003). A woman's leadership style will encourage greater CSR disclosure practices (De Celis, VelascoBalmaseda, De Bobadilla, Alonso-Almeida, $\&$ Intxaurburu-Clemente, 2015). In line with this study, the results of research conducted by Harrigan (1981), Kesner (1988), Stults (1979), Bear et al (2010) quoted from (Martínez et al., 2018) stated that women directors are more sensitive to CSR activities than men, because women have tendencies in the fields of education, regulations and non-profit activities. From the description above, the hypothesis can be formulated as follows:

H1: the existence of a female board of directors has a positive effect on CSR disclosure

Nationality diversity is a nationality value that is inherent in a person that shows where the individual came from and where he was born (Rahindayati, 2015). Nationality diversity will create a sense of love and fanatics for the country where it was born. Nationality value will also affect an individual's performance at work (Hadya $\&$ Susanto, 2018).

The background of board members who are from abroad has become an important aspect in the composition of the board. Research conducted by (Majeed, Aziz, \& Saleem, 2015) shows positive results between the influence of nationality diversity and CSR disclosure. Because of his love for his homeland, then encourage individuals to try to preserve the life and assets of their country. So that conclusions can be drawn as follows:

\section{H2: Nationality diversity has a positive effect on CSR disclosure}

The level of education shows the extent of the level of competency that individuals have in carrying out their work. The level of competence also shows how well the individual's thinking patterns in carrying out various activities in his life (Hadya \& Susanto, 2018). When a member of the board of directors has an academic influence that can affect the disclosure of corporate social responsibility, there are several reasons for this. The first is, members of the board of directors who have a higher level of education, will have a positive influence on individual concerns related to ethics. That is, 
the board of directors with higher education will have more attention to ethical issues. Many studies have also shown that higher academic degrees tend to have a high concern for CSR issues compared to boards of directors who have lower levels of education.(Zhuang \& Chang, 2018).

Other studies reveal that the board of directors with a background has examined the issue of corporate social responsibility or other related fields that have greater motivation to encourage companies to achieve superior CSR performance because they know the benefits more than CSR disclosure to the company.

In a study conducted by Rahindayati (2015) proves that the level of education has a positive effect on CSR disclosure (Rahindayati, 2015). This shows that the higher the education of the board of directors, the higher awareness of environmental awareness can be concluded as follows:

\section{H3: Board of directors' education has a positive effect on CSR disclosure}

\section{Discussion}

\section{Legitimacy Theory}

The legitimacy theory emphasizes that organizations continue to ensure that companies adhere to the bonds and norms that apply in the communities in which they operate. This theory implies that there is a social contract between the company and the surrounding community.

The company needs to ensure that all existing provisions are not violated to maintain the status of good legitimacy for the company in the eyes of the community, to enable the company to continue its existence and survival of the company in the community. In the theory of legitimacy, society is considered as a whole or whole without considering individuals separately. So in this theory relating the relationship between companies or organizations and the wider community. The company needs the community for the company's survival. For example, companies need human resources and raw materials from the community. The surrounding community will work as company employees and the community will also provide raw materials for the company to operate (Fernando \& Lawrence, 2014).

However, operating an organization or company in this way is not always easy, this is due to the variety of norms and expectations of society that are constantly changing and thus difficult to realize in accordance with organizational goals. As a result of the discrepancy, a legitimate threat will arise as a result of unexpected events that can affect the company's reputation. These gaps or threats can be a risk for the company, unless the company implements a 
legitimacy strategy appropriately (Fernando \& Lawrence, 2014).

Disclosure of CSR activities and reporting of corporate social responsibility activities is carried out to maintain, obtain and regain company legitimacy. Therefore, in the theory of legitimacy the desire to legitimize the company's operational activities through CSR disclosure activities is considered as a motivation to encourage management's decision to disclose their social activities. When management is motivated by this motivation, the company will do whatever it takes to try to maintain the company's image. To increase organizational legitimacy, based on previous research, the company only reveals positive news and avoids negative news, thereby, the legitimacy of the company will increase.

\section{Islamic Social Responsibility (ISR)}

In the perspective of Islamic expression, there are two general requirements, namely full disclosure and social accountability. The concept of social accountability is related to the principle of full disclosure which aims to serve the public interest (RM Haniffa \& Cooke, 2002). In the context of Islam, the ummah (public) has the right to know the operational impact of a company related to its welfare and the existence of disclosure or notification whether the objectives set have been achieved. One way to provide full disclosure in the context of Islam is the ISR (Islamic Social Reporting).

According to Haniffa, ISR is very important because it shows the company's accountability to the public. ISR also shows the transparency of business activities and in accordance with the spiritual needs of Muslims. In the context of accountability, one of the main objectives of accounting is to provide a fair flow of information between accountants and users of financial statements (R. Haniffa, 2002).

In the context of Islam, the first and main purpose of reporting is to show that the company's activities are running in accordance with sharia principles. Whereas the second purpose of reporting from an Islamic point of view is the judgment of decision makers, which in the western view, this is their main goal. So that Sharia-based company financial reporting is emphasizing the principle of full disclosure through accountability in meeting the needs of the wider community. The meaning of full disclosure here is that a Sharia bank must provide all necessary information to the public about the company's activities (R. Haniffa, 2002).

ISR indexes are disclosure items that are used as indicators in reporting the social performance of Islamic business institutions. Haniffa made five ISR Index disclosure themes, namely Funding and 
Dessy Noor Farida, The Influence Of Gender Diversity, Nationality, And Education Of The Board....

Investment Themes, Product and Service Themes, Employee Themes, Community Themes, and Environmental Themes. Then developed by Othman by adding a disclosure theme, namely the theme of Corporate Governance (Othman \& Mara, 2010).

\section{Research result}

Based on table 1, it can be concluded that the research data from 10 sample companies have passed the classical assumption test. Total research observation data totaled 52 data.

\section{Table 1}

Summary of Classical Assumption Test

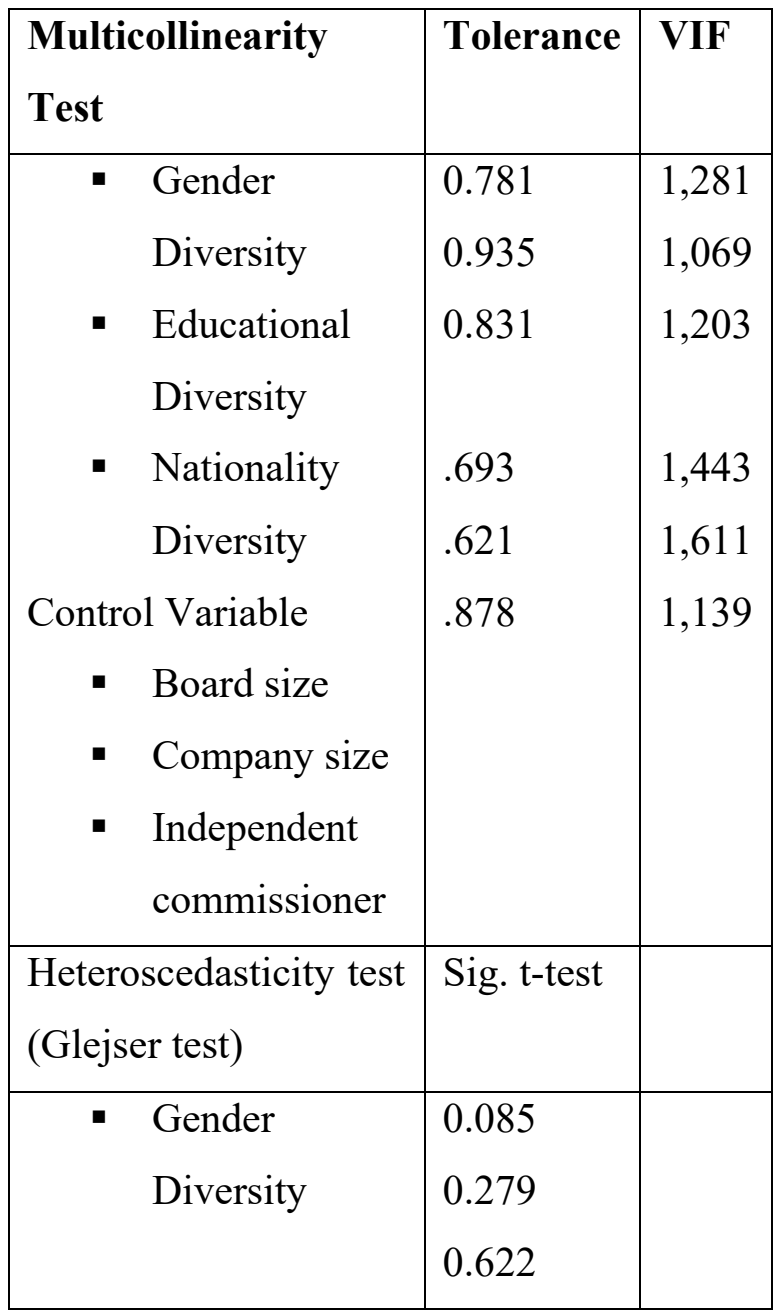

\begin{tabular}{|c|c|c|c|}
\hline $\begin{array}{c}\text { Educational } \\
\text { Diversity } \\
\text { - } \text { Nationality } \\
\text { Diversity } \\
\text { Control Variable } \\
\text { - Board size } \\
\text { - Company size } \\
\text { - Independent } \\
\text { commissioner }\end{array}$ & $\begin{array}{l}0.647 \\
0.066 \\
0.189\end{array}$ & & \\
\hline $\begin{array}{l}\text { Durbin- } \\
\text { Watson } \\
\text { test }\end{array}$ & 2,792 & & \\
\hline Normality Test & & & \\
\hline $\begin{array}{c}\text { kolmogorov- } \\
\text { Smirnov test }\end{array}$ & 0.593 & & \\
\hline - Adj R Square & 0.656 & & \\
\hline $\mathrm{N}=52$ & & & \\
\hline \multicolumn{4}{|c|}{ Source: Secondary data processed (2019) } \\
\hline \multicolumn{4}{|c|}{ The independent variable and control } \\
\hline Hypothesis test & Coefficient & $\begin{array}{l}\mathrm{t} \\
\text { value }\end{array}$ & Sign \\
\hline $\begin{array}{cl}\text { - } & \text { Gender } \\
& \text { Diversity } \\
\text { - } & \text { Educational } \\
\text { Diversity } \\
\text { - Nationality } \\
\text { Diversity } \\
\text { Control Variable } \\
\text { - Board size } \\
\text { - Company size }\end{array}$ & $\begin{array}{l}-0,059 \\
-0,033 \\
0.295\end{array}$ & $\begin{array}{l}- \\
1,154 \\
- \\
0,699 \\
6,770\end{array}$ & $\begin{array}{l}0.255 \\
.488 \\
0,000 \\
0.818 \\
0.002 \\
.648\end{array}$ \\
\hline
\end{tabular}


- Independent commissioner

Source: Secondary data processed (2019)

Based on the results of testing the hypotheses in table 2 , it is obtained evidence that the calculated $t$ value of -1.154 with a significance of 0.255 , and the variable coefficient for gender diversity is -0.059 . This means that gender diversity has no effect on disclosure. This means that the first hypothesis (H1) is rejected.

Based on research conducted by Seierstad, Warner-Søderholm, Torchia \& Huse (2017) the role of the female director in the board of directors is very important, this is due to 2 reasons, namely business and justice. The first reason is based on the premise that having women on the board of directors can improve performance. Whereas the second reason focuses on the existence of gender equality between female directors and male directors.

According to Johston and Packer (1987) in the 1980s, the existence of women and ethnic minorities in management in US companies was very minimal, and this became a management problem. This changed when the company began to provide opportunities for women to occupy the management area assuming that women have the ability to increase economic efficiency and increase competitive advantage in the company (Martinez, Beloms, \& Sempere, 2018).

Female directors have better skills than male directors, and this results in improved organizational performance by the diversity of the board of directors helping to understand labor market volatility that can cause wider demographics to penetrate the market and attract potential customers and suppliers (Robinson \& Dechant, 1997).

However, the presence of women on the board of directors of Islamic banking in Indonesia did not affect the disclosure of corporate social responsibility. This shows that in Indonesia the presence of women on the board of directors is still quite low. This is proven by research data which shows that the average female presence in the board of directors is only around $19 \%$.

In research conducted by Wei, Ding, \& Kong (2017) shows that if there are only one or two women on the board of directors, it will not have an impact on corporate social responsibility disclosure. In the study it was also explained that the role of women in the board of directors would have a significant effect when there were more than 3 women on the board. This can also be seen from the data of this study, which shows the average number of female boards of directors is only around one and two for each sample company. This shows that the presence of women in the board of directors is only a 
symbol of gender differences. The board of directors will not consider or seek advice from women directors when making decisions. Meanwhile, due to the existence of only a small number of women,

When there are at least three or more female directors, they will feel comfortable with their presence in the board of directors. The female directors will be more free in submitting their opinions and actively participating in the process of making decisions about the company. So a minimum of three female boards of directors will have a significant impact on disclosure of corporate social responsibility (Wei et al., 2017).

The results of this study are in line with research conducted by Farida, (2019), Byron \& Post (2016) and Manita, Bruna, Dang, \& Houanti, (2018b) which shows the results of the presence of women on the board of directors have a weak relationship with the disclosure of corporate social responsibility.

This research is not in line with research conducted by Kartikarini \& Mutmainah (2013), Fauziah, (2018), Rahma, (2018) and Setiawan, et al (2018) which states that female board members (female CEOs) influence voluntary corporate governance disclosure and CSR disclosure.

Based on the results of testing the hypotheses in table 2 , it is obtained evidence that the calculated $t$ value of 6.770 with a significance of 0.000 , and the coefficient of variable gender diversity of 0.295 . This means that nationality diversity affects the Disclosure of Corporate Social Responsibility. This means that the first hypothesis (H2) is accepted.

Nationality diversity is a nationality value that is inherent in a person that shows where the individual came from and where he was born (Rahindayati, 2015). Nationality diversity will create a sense of love and fanatics for the country where it was born. Nationality value will also affect an individual's performance at work (Hadya \& Susanto, 2018).

Research conducted by Ruigrok et al. States that foreign directors tend to have a closed personality. Therefore, they tend not to be affiliated with other directors because they tend to be independent. Foreign directors lack a strong network in the community where the company is located. This will affect his decision in disclosing corporate social responsibility (Ruigrok, Peck, \& Tacheva, 2007)

The background of board members who are from abroad has become an important aspect in the composition of the board. Research conducted by (Majeed et al., 2015) shows positive results between the influence of nationality diversity and CSR disclosure. Because of his love for his homeland, then 
encourage individuals to try to preserve the life and assets of their country.

In a study conducted by Haniffa and Cooke, with a sample of public companies in Malaysia, where the nationality diversification proxy uses ethnicity, it was concluded that the percentage of board members who came from within the country was positively related to the amount of information presented by the company, whereas directors from outside the country did not relates to the amount of information presented by the company (RM Haniffa \& Cooke, 2002).

The results of this study are consistent with research conducted by (RM Haniffa \& Cooke (2002), Setiawan et al., (2018), Women (2019), Romdioni \& Ulita, (2019)and Ruigrok et al., (2007). The results of the study reinforce the suspicion that if many boards of directors come from within the country, more will be disclosed related to corporate social reports due to their love for their homeland towards the country, thereby increasing their concern for the surrounding environment. But the results of this study contradict the results of research conducted by Kesaulya \& Febriany, (2018) which states that the foreign board of directors, the foreign board of commissioners and the foreign CFO / CEO do not affect the value of the company.
Based on the results of testing the hypotheses in table 2 , it is obtained evidence that the calculated value of $t$ is -0.699 with a significance of 0.488 , and the variable coefficient of educational diversity is 0.033 . This means that educational diversity does not affect Corporate Social Responsibility Disclosure. This means that the first hypothesis (H3) is rejected.

The level of education shows the extent of the level of competency that individuals have in carrying out their work. The level of competence also shows how well the individual's thinking patterns in carrying out various activities in his life (Hadya \& Susanto, 2018). When a member of the board of directors has an academic influence that can affect the disclosure of corporate social responsibility, there are several reasons for this. The first is, members of the board of directors who have a higher level of education, will have a positive influence on individual concerns related to ethics. That is, the board of directors with higher education will have more attention to ethical issues. Many studies have also shown that higher academic degrees tend to have a high concern for CSR issues compared to boards of directors who have lower levels of education (Zhuang \& Chang, 2018).

In this study the level of education does not affect the disclosure of corporate social responsibility. This is consistent with the 
research done by Kyun, Oh, Hyun, Myoung, \& Jang (2015) who found a non-linear pattern (U-Shape) in the relationship between board education and CSR disclosure. This different pattern can be explained by the existence of cultural differences between countries. Indonesia is a country with a collective culture, in contrast to a western country which is more individualistic. Collectivistic culture often inhibits diversity and individuality by emphasizing shared social norms and shared identities. And this culture often looks for harmony as a social policy. If some directors have a minority view, they may feel pressure to comply with group decisions. Therefore the diversity of the council related to education will not have a positive influence on CSR disclosure.

However, if diversity increases, then directors may feel more free to give their own opinions and in turn, they will tend to be more committed to CSR disclosure. In this study, board members who have an economic education background of approximately $55 \%$ compared to the board of directors who have no economic background. One reason may be due to different economic conditions.

The economic environment in developed countries and developing countries will cause differences in the strictness of accounting standards, which in turn, will cause differences in disclosure of information in general and CSR information in particular (El-bassiouny \& El-Bassiouny, 2018). If the economic environment is not healthy it will have a negative impact on CSR. Companies with lower financial performance will usually prefer to oppose CSR disclosures on the grounds of limited resources.

The first control variable is board size, which is measured by the total number of boards of directors. With more and more members of the board of directors there will be more expertise and knowledge (Kyun et al., 2015).

According to research conducted by Jaw \& Lin (2009), that company executives are the main figures responsible for strategic changes in the organization. Research conducted by Jamali, Safieddine, \& Rabbath (2008) shows that some managers perceive that strong governance policies are a necessary instrument in implementing CSR.

The second control variable is company size. The size of the company is proxied by the total assets being logged. According to previous research, the relationship between company size and CSR disclosure is positively related. This indicates that the larger the size of the company, the more voluntary disclosure will be, such as corporate social responsibility reports. A larger company size will bring in many 
stakeholders, and the company must respond to the needs and interests of stakeholders.

In this study, the results show that the firm size control variable has a positive and significant effect on the disclosure of corporate social responsibility. This is also in line with research conducted by RM Haniffa \& Cooke, (2002). The argument that can be built is that the larger the size of the company will tend to receive greater attention from the general public and therefore, this is a big pressure for companies to provide CSR information to the public. Most of the general public now has a great awareness of the environment, therefore, this has become one of the company's attention to care for the environment. It also forces the company to respond to various social and environmental problems around the company as soon as possible (Carina, Watson, \& Woodliff, 2014).

The third control variable is the independent commissioner. The separation of ownership and control between shareholders and managers, will cause problems of long-term interests. According to agency theory, agency problems can be overcome by monitoring conducted by an independent party. One of the most effective ways to monitor managers is to assign someone from outside the company to supervise. With the presence of board members from outside the company, then the independence of the directors can be used to bridge the problems between managers and shareholders. The independent board of commissioners can oversee the running of the company to comply with the rules. They can encourage managers to make corporate social responsibility disclosures.

For the banking world, the role of independent commissioners may not yet be effective. The board of commissioners has not yet carried out their duties and functions to the full. Restuningdiah (2010) states that, if the independent board of commissioners does not have time for the company because of their busy schedule, the independent commissioners' existence will be ineffective.

The second reason is the lack of ability and knowledge and experience of the independent board of commissioners themselves. The competence of the board of commissioners plays an important role in decision making. So that if an independent board of commissioners has good competence, it will improve the quality of decision making at the board of commissioners level (Olivar, 2014).

The third reason is the possibility that the independence of the board of commissioners is still not independent so 
that it will affect the oversight function. The independence of the board of commissioners will cause a lack of encouragement for management to make CSR disclosures (Aniktia \& Khafid, 2015)

\section{Conclusion}

The results showed that the variable gender diversity had no significant effect on CSR disclosure. This is because in Indonesia the presence of women on the board of directors is still quite low. This is proven by research data which shows that the average female presence in the board of directors is only around 19\%. Nationality diversity variable has a significant influence on CSR disclosure. The board of directors who come from within the country, will reveal more corporate social responsibility reports because of the love of their homeland for the country, thus increasing their concern for the surrounding environment. Educational diversity variable does not affect CSR disclosure. Collectivistic culture in Indonesia often inhibits diversity and individuality by emphasizing shared social norms and shared identities. If some directors have a minority view, they may feel pressure to comply with group decisions.

Theoretically, this research has implications for the development of financial accounting theories regarding the theory of legitimacy. The results of this study indicate that the diversity that exists on the board of directors, which consists of gender differences, nationality differences and educational differences not all can affect corporate social disclosure. Of the three diversity, only nationality diversity affects social disclosure. Thus the results of this study have implications for encouraging the direction of financial accounting research and good corporate governance to further analyze the other variables that influence CSR disclosure in Sharia banking in Indonesia, so as to overcome problems related to the banking industry's maximum disclosure. CSR in Indonesia.

\section{REFERENCE}

Aguilera, R. V, Williams, C. A., Conley, J. M., \& Rupp, D. E. (2006). Corporate Governance and Social Responsibility : A Comparative Analysisi of The UK and The US. Journal Compilation, 14(3), 147-158. https://doi.org/10.1049/ic:19950232

Aniktia, R., \& Khafid, muhammad. (2015). Pengaruh Mekanisme Good Corporate Governance dan Kinerja Keuangan Terhadap Pengungkapan Sustanability. Accounting Analysisi Journal, 4(3), 110.

Byron, K., \& Post, C. (2016). Women on Boards of Directors and Corporate Social Performance : A Meta-Analysis. An International Review, 1-15. https://doi.org/10.1111/corg.12165

Carina, C. M., Watson, J., \& Woodliff, D. (2014). Corporate Governance Quality and CSR Disclosures. Business Ethics Journal, (125), 59-73. https://doi.org/10.1007/s10551-013- 
$1887-8$

carter, david A; Simkins, Betty ; Simpon, G. (2003). Corporate Governance , Board Diversity, and Firm Value. Economics Bulletin, 38, 33-53.

De Celis, I. L. R., Velasco-Balmaseda, E., De Bobadilla, F. S., Alonso-Almeida, M. D. M., \& Intxaurburu-Clemente, G. (2015). Does having women managers lead to increased gender equality practices in corporate social responsibility? Business Ethics, 24(1), 91-110.

https://doi.org/10.1111/beer.12081

El-bassiouny, D., \& El-Bassiouny, N. (2018). Diversity , corporate governance and CSR reporting $\mathrm{A}$ comparative analysis between toplisted firms in Egypt, Germany and the USA. Management of Environmental Quality: An International Journal, 122. https://doi.org/10.1108/MEQ-122017-0150

Farida, D. N. (2019). Pengaruh Diversitas Gender Terhadap Pengungkapan Sustainability Development Goals. Jurnal Akuntansi Indonesia, 8(2), 89107.

Fauziah, F. E. (2018). Diversitas Gender Dan Nilai Perusahaan Dengan Corporate Social Responsibility Sebagai Variabel Intervening. Media Ekonomi Dan Manajemen, 33(2), 187204.

Fernando, S., \& Lawrence, S. (2014). A theoretical framework for CSR practices: Integrating legitimacy theory , stakeholder theory and institutional theory. Journal of Theoretical Accounting, 10(February 2018), 149-178.

Hadya, R., \& Susanto, R. (2018). Model Hubungan Antara Keberagaman Gender, Pendidikan Dan Nationality Dewan Komisaris Terhadap Pengungkapan Corporate Social Responsibility. Jurnal Benefita, 3(2), 149.

https://doi.org/10.22216/benefita.v3i2. 3432
Haniffa, R. (2002). Social Responsibility Disclosure: An Islamic Perspective. Indonesian Management and Accounting Research, 1, 128-146.

Haniffa, R. M., \& Cooke, T. E. (2002). Culture , Corporate Governance and Disclosure in Malaysian Corporations. Abacus, 38(3), 317-349.

Jamali, D., Safieddine, A. M., \& Rabbath, M. (2008). Corporate governance and corporate social responsibility synergies and interrelationships. Corporate Governance: An International Review, 16(5), 443-459. https://doi.org/10.1111/j.14678683.2008.00702.x

Jaw, Y. L., \& Lin, W. T. (2009). Corporate elite characteristics and firm's internationalization: CEO-level and TMT-level roles. International Journal of Human Resource Management, 20(1), 220-233. https://doi.org/10.1080/095851908025 28797

Kartikarini, N., \& Mutmainah, S. (2013). Analisis Pengaruh Diversitas Gender Terhadap Voluntary Corporate Governance Disclosure Dalam Laporan Tahunan Perusahaan. Diponegoro Journal Of Accounting, 2(1), 1-15.

Kesaulya, F. A., \& Febriany, N. (2018). Kebangsaan Board Of Blockholders Terhadap Nilai Perusahaan : Studi Pada Perusahaan Publik Di Indonesia. Kompartemen : Jurnal Ilmiah Akuntansi, XVII(2), 60-68.

Kyun, Y., Oh, C. W., Hyun, J., Myoung, P., \& Jang, G. (2015). Exploring the Relationship Between Board Characteristics and CSR: Empirical Evidence from Korea. Journal of Business Ethics. https://doi.org/10.1007/s10551-0152651-Z

Majeed, S., Aziz, T., \& Saleem, S. (2015). The Effect of Corporate Governance Elements on Corporate Social Responsibility (CSR) Disclosure: An Empirical Evidence from Listed 
Dessy Noor Farida, The Influence Of Gender Diversity, Nationality, And Education Of The Board....

Companies at KSE Pakistan. International Journal of Financial Studies, 3(4), 530-556. https://doi.org/10.3390/ijfs3040530

Manita, R., Bruna, M. G., Dang, R., \& Houanti, L. (2018). Board gender diversity and ESG disclosure: evidence from the USA. Journal of Applied Accounting Research, 19(2), 206-224. https://doi.org/10.1108/JAAR-012017-0024

Martinez, maria consuelo pucheta, Beloms, I., \& Sempere, G. O. (2018). The Association between board gender diversity and financial reporting quality,corporate performance and corporate social responsibility disclosure :A literature review. Emerald Insight, 0-27.

Martínez, M. C. P., Oms, I. B., \& OlcinaSempere, G. O. (2018). The association between board gender diversity and financial reporting quality, corporate performance and corporate social responsibility disclosure: A literature review. emeraldinsight (Vol. 39).

Olivar, D. L. (2014). Corporate Social Responsibility And Corporate Governance: A Look Into Possible Integration In The Philippine Setting International Journal of Information Technology and Business Management, 25(1), 106-120.

Othman, R., \& Mara, U. T. (2010). Islamic Social Reporting Of Listed Companies In Malaysia. International Business \& Economics Research Journal, 9(4), 135-144.

Putri, A. S. . (2019). Keragaman Dewan Direksi dan Pengaruhnya Terhadap Pengungkapan Corporate Social Responsilibility di Indonesia.

Rahindayati, N. M. (2015). Pengaruh diversitas pengurus pada luas pengungkapan.

Rahma, I. (2018). Analisis Pengaruh Keragaman Gender Dan Corporate Governance Terhadap Pengungkapan Lingkungan ( Environmental Disclosure).
Rahmat, B. Z. (2017). Corporate Social Responsibility Dalam Perspektif Etika Bisnis Islam. Amwaluna: Jurnal Ekonomi Dan Keuangan Syariah, 1(1), 98-113.

Restuningdiah, N. (2010). Mekanisme GCG dan Pengungkapan Tanggung Jawab Sosial terhadap Koefisien Respon Laba. Jurnal Keuangan Dan Perbankan, 14(3), 377-390. https://doi.org/10.1007/BF02093482

Robinson, G., \& Dechant, K. (1997). Building a business case for diversity. Academy of Management Perspectives, 11(3), 21-31. https://doi.org/10.5465/ame.1997.9709 231661

Romdioni, A. N., \& Ulita, A. S. (2019). Pengaruh Keanekaragaman Manajemen Terhadap Luas Pengungkapan Tanggung Jawab Sosial Perusahaan. Musamus Accounting Journal, 1(2), 108-116.

Ruigrok, W., Peck, S., \& Tacheva, S. (2007). Nationality and Gender Diversity on Swiss Corporate Boards. Corporate Governance An International Review, 15(4), 546-557. https://doi.org/10.1111/j.14678683.2007.00587.x

Seierstad, C., Warner-Søderholm, G., Torchia, M., \& Huse, M. (2017). Increasing the Number of Women on Boards: The Role of Actors and Processes. Journal of Business Ethics, 141(2), 289-315. https://doi.org/10.1007/s10551-0152715-0

Setiawan, D., Hapsari, R. T., \& Wibawa, A. (2018). Dampak Karakteristik Dewan Direksi Terhadap Pengungkapan Corporate Social Responsibility Pada Perusahaan Pertambangan Di Indonesia. Jurnal Ilmiah Manajemen, $\operatorname{VIII}(1), 1-15$.

Stephenson, C. (2004). Leveraging diversity to maximum advantage: The business case for appointing more women to boards. Ivey Business Journal, (Oktober), 1-6. 
Teraspr. (2016). Riset NUS : Kualitas CSR di Indonesia Rendah.

Wei, F., Ding, B., \& Kong, Y. (2017). Female Directors and Corporate Social Responsibility: Evidence from the Environmental Investment of Chinese Listed Companies. Sustainability, 9(October), 1-19. https://doi.org/10.3390/su9122292

Zhuang, Y., \& Chang, X. (2018). Board Composition and Corporate Social Responsibility Performance : Evidence from Chinese Public Firms. Sustainability, 10(2752), 1-12. https://doi.org/10.3390/su10082752 